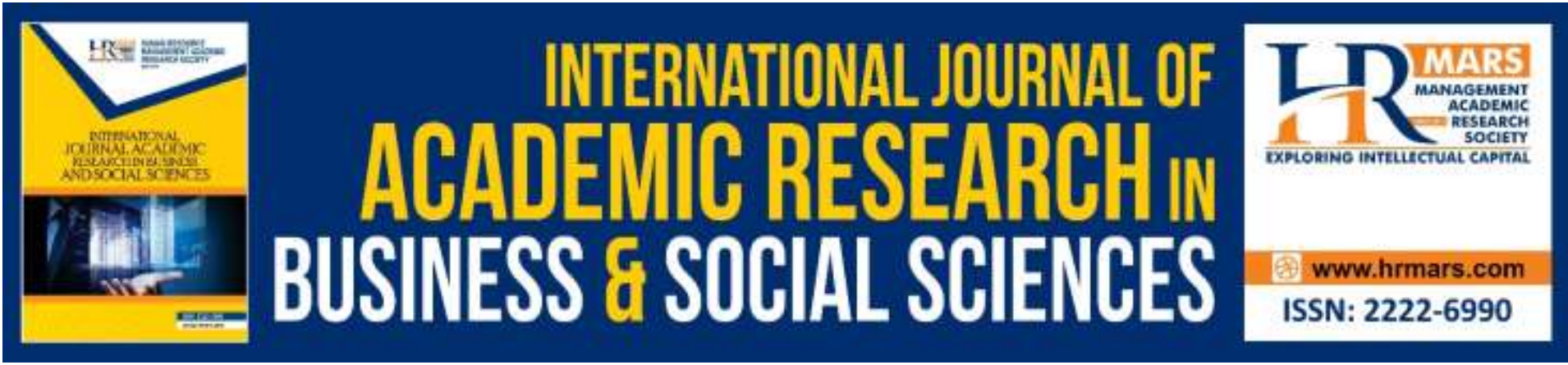

\title{
An Evaluation of the Role of Supreme Audit Institutions in Reduce of Audit Failure to Promote Economic Development: The Case of the Federal Board of Supreme Audit of Iraq
}

\author{
Waleed Khalid Salih, Mustafa S. Almajdob
}

To Link this Article: http://dx.doi.org/10.6007/IJARBSS/v9-i9/6288

DOI: $10.6007 /$ IJARBSS/v9-i9/6288

Received: 02 July 2019, Revised: 02 August 2019, Accepted: 23 August 2019

Published Online: 11 September 2019

In-Text Citation: (Salih \& Almajdob, 2019)

To Cite this Article: Salih, W. K., \& Almajdob, M. S. (2019). An Evaluation of the Role of Supreme Audit Institutions in Reduce of Audit Failure to Promote Economic Development - The Case of the Federal Board of Supreme Audit of Iraq. International Journal of Academic Research in Business and Social Sciences, 9(9), 252-265.

Copyright: (C) 2019 The Author(s)

Published by Human Resource Management Academic Research Society (www.hrmars.com) This article is published under the Creative Commons Attribution (CC BY 4.0) license. Anyone may reproduce, distribute, translate and create derivative works of this article (for both commercial and non-commercial purposes), subject to full attribution to the original publication and authors. The full terms of this license may be seen

at: http://creativecommons.org/licences/by/4.0/legalcode

Vol. 9, No. 9, 2019, Pg. 252 - 265

Full Terms \& Conditions of access and use can be found at http://hrmars.com/index.php/pages/detail/publication-ethics 


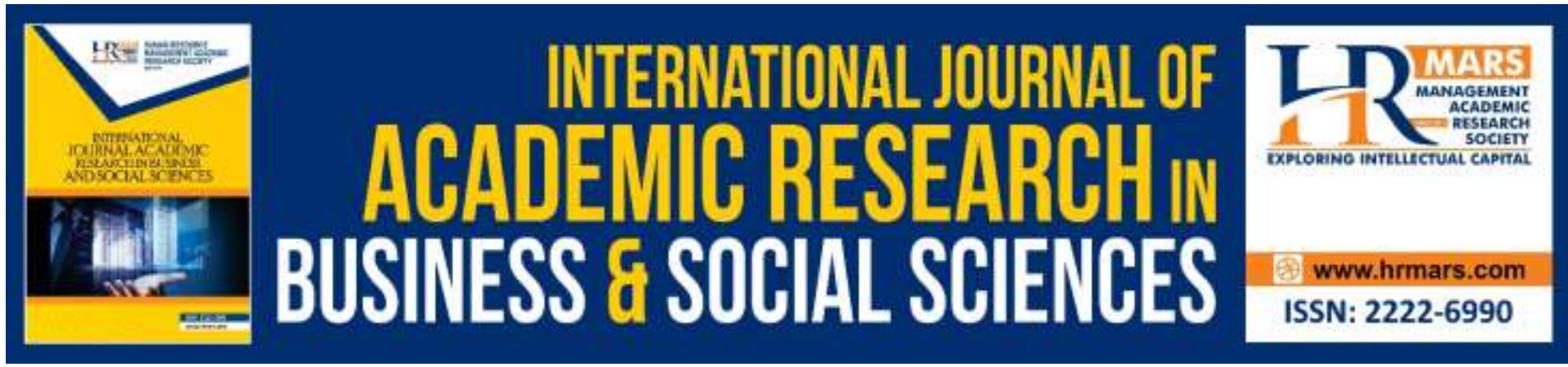

\title{
An Evaluation of the Role of Supreme Audit Institutions in Reduce of Audit Failure to Promote Economic Development: The Case of the Federal Board of Supreme Audit of Iraq
}

\author{
Waleed Khalid Salih \\ College of Administration and Economics, Accounting Department, Uniersity of Anbar, Iraq \\ Email: Waleed cpa@yahoo.com \\ Mustafa S Almajdob \\ Department of Economic, Faculty of Economics and Business/University Malaysia Sarawak) \\ Email: msalmajdob@gmail.com
}

\begin{abstract}
There is increased public outcry in Iraq on the government's wastage of public spending, corruption, high recurrent expenditures and ineffective budget performance by different government entities. This led to increase in pressure on the Supreme Audit Institutions (SAIs) to reduce of audit failure in order promote economic development. this study aimed to examine the role of supreme audit institutions in reduce of audit failure and examine the Impact of Reduce Audit Failures on promote economic development, the target population in the present study is linked to auditors from the Federal Board of Supreme Audit of Iraq. The total number of Auditors 1734 Auditor. The sample size (n) is 317. The Partial Least Squares Structural Equation Modeling (PLS-SEM) was used to test the research model, with Smart PLS 3 specifically employed to test the research hypotheses. The findings of the study showed that the SAls efforts to lessen corruption are its major contribution in preventing corruption, reduce of audit failure and in supporting accountability and transparency with the main aim of supporting a robust financial-management system and promote economic development. Therefore, it is crucial that SAls become the linchpin of the integrity of the country as they are responsible for auditing government income and expenditure, the watchdog over financial integrity and the credibility of information provided.
\end{abstract}

Keywords: Supreme Audit Institutions, Audit Failure, Economic Development.

\section{Introduction}

The environment of the public sector audit generally has a monopolistic nature with the SAIs responsible for government auditing (Clark et al., 2007). The SAls have different roles and functions that are important to the public, the legislature as well as the government and they have different audits and inspections roles in different entities of the government. The audits 
can be conducted through requests or on a spontaneous manner (Ibrahim, 2010). SAls are basically independent, non-political entities that perform auditing for governments in order to make sure that public funds are effectively and properly used, administrative activities are properly executed and communication of information to relevant public authorities and the public through reports publication are ensured (Rankokwane, 2008). SAls also play a significant role in reinforcing accountability and good governance by assisting governments in their enhancement of transparency and accountability, combat corruption, maintain public trust and promote the efficient and effective receipt and employment of public resources for the citizens of the country (Odia, 2014). According to Sevilla (2005), a decentralized environment has to have disciplined public spending, positive institutional relationships, a maintained negotiation platform, management cooperation, permanent and transparent reporting as well as cooperative control structures throughout different government levels. In establishing the key role in SAls in the context of financial management and control system, it should be kept it mind that such entities have the essential legal powers/tools to audit the entire public funds, resources and activities and relay audit findings to the parliament to assist parliamentary monitoring over executives and to make it known to the public (Kayrak, 2008). In a related study, Power (1997) stated that independent auditing is required in majority of modernist conceptions of accountability as it improves the information in terms of its credibility and legitimacy upon which formal financial accountability is based on. Stated clearly, SAls auditing activities should be devoid of executive intervention that would employ the audit reports in supporting public-financial management (Kayrak, 2008). Studies in literature dedicated to SAls independent of different jurisdictions focused generally on the evaluation of the independent level obtained by the institutions and the effect of such independence on the public officials' discharge of account abilities (Fan et al., 2012). Therefore, it is crucial that SAls become the linchpin of the integrity of the country as they are responsible for auditing government income and expenditure, the watchdog over financial integrity and the credibility of information provided (Dye \& Stapenhurst, 1998). In fact, the SAls efforts to lessen corruption are its major contribution in preventing corruption and in supporting accountability and transparency with the main aim of supporting a robust financial-management system (Borge, 1999).

"SAls are autonomous, independent, non-political organizations that audit governments to ensure the proper and effective use of public funds; the development of sound financial management; the proper execution of administrative activities; and the communication of information to public authorities and the general public through the publication of objective reports" (Odia, 2014). SAls are members of the International Organization of Supreme Audit Institutions (INTOSAI), which is also an autonomous, non-political body with special consultative status with the Economic and Social Council of the United Nations (Ibrahim, 2010).

\section{Problem Statement}

In the past few years, audit quality has attracted attention as a tool used to assess the auditing effectiveness and in recent times increasing importance has been placed on SAIS to conduct quality auditing (Karapetrovic \& Willborn, 2000). In a related study, Nuri and Al-Lahibi (2013) revealed some barriers to achieving effective auditing in the level of Federal Board of Supreme Audit of Iraq. FBSA auditing in Iraq is linked to the competence, experience and 
independence of the auditor and his ability to determine material errors and misstatements (Salih \& Hla, 2015). In this regard, auditing failures have led to debates concerning the new requirement in place (Hamdan, 2011) to reinforce quality auditing (Hagman \& Persson, 2014). In prior studies, audit failures have been evidenced to tarnish auditor reputation through loss of market share (Fafatas, 2010). In this background, quality of audit may be considered conceptually as a continuum that ranges from very low to very high audit quality. In addition, audit failures arise on the lower quality continuum, while audit quality is at the opposite, with the former having the possibility of leading to business failure, corruption as well as other negative consequences. Moreover, audit failures lead to minimized perceived audit quality of firms (Francis, 2004; Bing et al., 2014; Hagman \& Persson, 2014; Fafatas, 2010; Beattie et al., 2010). According to Kayrak (2008), corruption happens on a global level in different ways and forms notwithstanding the development level of the country. More recently, there is increased public outcry in Iraq since 2003 on the government's wastage of public spending, corruption, high recurrent expenditures, governance costs and ineffective budget performance by different government entities. In this regard, Tas (2012) evidenced that public sector corruption is rife in Iraq, especially among the public officials in the higher echelons and it has the potential to lessen economic development and good country governance.

\section{The Responsibility of Combating Corruption in the Iraqi Public Sector}

In the Iraqi public sector, the Federal Board of Supreme Audit of Iraq (FBSA) is the main entity responsible of combating corruption. It is professional independent and neutral institution established in 1927 and it plays a key role justifying public funds and promoting the auditees' efficiency in government institutions as well as public officers. The FBSA holds the responsibility of auditing the Iraqi government accounts and monitoring public contracts. It is deemed to be one of the pioneering institutions in the country. Moreover, the Board mandate has gone through evolution throughout the years and was last modified in 2011 (Federal Law 31). It is basically an independent institution in terms of financial and administrative duties and it reports to the Parliament.

Moreover, the FBSA is responsible for safeguarding public interest as it identifies and refers cases of fraud, waste and abuse to the anti-corruption entities. In its participatory role in fighting corruption, it makes use of the principles of transparency and accountability and ensures that public funds are efficiently used, the efficiency of institutions are increased, and public sectors are audited, audits are enhanced, and standards of accounting and management are aligned with international standards (Odia, 2014). It also ensures that accounting and auditing professions and systems are developed. Its other responsibilities include the control and auditing of parties' accounts based on control and financial laws, regulations and instructions, conducting investigations into expending efficiency and use of public wealth and reporting it as required by the national legislative authority (Ibrahim, 2010).

\section{Agency Theory}

Although agency theory was rooted in economics and finance, it has been used in many other sciences including accounting, marketing, political science, organizational behavior and sociology (Elghrabawy, 2012). Agency theory can explain through the following: theorizing that the company consists of various agreements between the company owners (principals) and the management (agents). They define an agency relationship as "a contract under which one or more persons engage another person (the agent) to perform some service on their 
behalf which involves delegating some decision making authority to the agent (Ratsula, 2010). According to Trotman (2013) the important idea in the agency relationship is the selection of appropriate governance mechanisms that reflects an efficient alignment of principal and agent interests as well as a reduction of agency costs. Agency theory suggests contractual mechanisms such as putting auditing in place to monitor management to address the separation in ownership and control.

Elghrabawy, (2012) argues that managers also demand monitoring services to ensure that they are not accountable to the client. This is done through the appointment of an independent external auditor to validate the assertions made by the managers. Argue the need for the verification by an independent third party of financial reports which prepared by these managers, these financial reports are used to evaluate managers' performance, He has also pointed out to monitoring made directly by the principal would be costly (Ahmad, 2012). Based on agency theory, one of the most cost-efficient ways is using different external and internal monitoring services by bringing an independent and trusted party to verify the reported information (Ratsula, 2010; Xi, 2013) conclude that from the agency perspective, the independent auditor central mission is to ensure that management's actions are aligned with stakeholders' interests.

Agency theory can help explain the existence, role and responsibilities of the internal and external audit function, and explain the important main determinants for internal audit quality (skills, technical skills, personality traits, experience and objectivity, firm culture). (Ahmad, 2012; Trotman, 2013). In the agency theory framework, the audit can be considered a monitoring device to control relationships between parliament and agents (government). The agent increases confidence in its activities by showing that its activities are controlled (Sweeney, 2001). Also it can be used agency theory to explain that it is in the interest of management to ensure existence of a strong audit department to the customer receiving audit services (Abdul-Hussein, 2013). Further that the primary aspect of agency theory is that the auditors must be independent. Without independence, the auditors would have no role to play within agency theory and their service would be of little or no value (Ratsula, 2010, Ahmad, 2012).

\section{The Role of Supreme Audit Institutions in Reduce of Audit Failure}

The SAI carries out various roles and functions which relevance to the public, legislature and government. They carry out various audits and inspections on the different governmental bodies. These audits can be carried out on request or spontaneously (Ibrahim, 2010). SAls are independent, non-political organizations that audit governments to ensure the proper and effective use of public funds and reduce of audit failure, the development of sound financial management; the proper execution of administrative activities, and the communication of information to public authorities and the general public through the publication of objective reports (Rankokwane, 2008).And plays an important role in strengthening accountability and good governance by helping various governments to improve performance, enhance transparency, ensure accountability, fight corruption, promote public trust and foster the efficient and effective receipt and reduce of audit failure(Odia, 2014). Sevilla (2005) Argue in a decentralized environment, public spending needs some degree of fiscal discipline, favorable institution relationships, a stable negotiation framework, management cooperation, permanent and transparent reporting and cooperative control structures across various levels of government. In figuring out the vital role of SAls in financial management 
and control system it should be underscored that they are granted essential legal powers and tools in order to audit all public funds, resources and activities and report audit findings to the parliament so as to reinforce parliamentary oversight over executive branch and publicize them (Kayrak, 2008).

Supreme audit institutions (SAIs), at least should be the linchpin of a country's integrity system. As the agency responsible for auditing government income and expenditure, the supreme audit institution acts as a watchdog over financial integrity and the credibility of reported information (Dye \& Stapenhurst, 1998). the role of SAls in curbing corruption is main contribution of SAls is to deter and prevent corruption by supporting accountability and transparency for the sake of a strong-financial management system and reduce of audit failure (Borge, 1999). According to that the following hypothesis is proposed;

H1: Supreme Audit Institutions have a significant and positive effect on Reduce of Audit Failure.

\section{The Impact of Reduce Audit Failures on Promote Economic Development}

Corruption encapsulates different activities ranging from petty bribery to grand corruption and is deemed a destructive element that destroys the political culture of nations, the just appropriation of resources, the well-being of societies, and the citizens' trust on their governments. Therefore, it is imperative to control corruption in order to promote economic development, increases the country's competitiveness, enhance social conditions and resolve the country's poverty issue (Kayrak, 2008). In study of the same caliber, Alkafaji (2007) revealed several indicators that confirm the significant relationship between poor quality review and audit failure or corruption. On the basis of the majority of the business scandals that occurred, it is imperative to enhance audit quality by conducting an analysis of the factors that influence effective auditing. In contrast, audit failures and corruption are costly to investors, auditors and to the society as a whole as this may lead to loss of public funds and weaken the economy and societal welfare. In the context of Iraq, corruption is rife among senior public officials in a manner that it may be considered as a threat to the development of the country's economy and its good governance (Sharman, 2008). In fact, failure to minimize corruption is related to the lack of access to anti-corruption entities among Iraqi ministries to examine allegations concerning corruption, making investigations dependent on information that has to be provided voluntarily upon the minister accused of corruption. This type of information gathering is evidently a flawed and weak one and as such, it is important to identify another method of exposing public sector corruption (TAS, 2012). The relationship between corruption and reduction of performance lies in the fact that performance refers to the achievement of task measured against established standards of accuracy, completeness and cost in the achievement of organization goals (Richards et al., 2008) while corruption prevents performance. According to Morrison and Shough (2009), audit failures have to be reduced to increase organizational performance and promote economic development and thus, the following hypothesis is proposed;

H2: Reduce of Audit Failures have a significant and positive effect on promote economic development.

\section{Methodology}

The target population in the present study is linked to auditors from the Federal Board of Supreme Audit of Iraq. The total number of Auditors 1734 Auditor (Plan of Action, 2017). Two 
conditions are met to determine the sample size number. First, the confidence level is set at $95 \%$ and the second, the confidence interval at $5 \%$. The sample size $(n)$ is 317 , and this result is consistent with Roscoe's sample rules. According to this rule, the sample size, which is more than 30 and less than 500, is suitable for most research (Hill, 1998). A random sample of sample selection is followed in the current study, as it generally provides greater accuracy in sample estimates without leading to significant cost increases.

For the purpose of this study, the data was collected through a questionnaire that contains the role of the SAls in reducing the audit failure in the Iraqi public sector and then the impact of reducing the audit failure to promote economic development. After confirming the reliability and validity of the questionnaire, the researcher personally distributed the questionnaire to the target sample, because sometimes the questions may be unclear and vague to the respondents if they are sent by mail (Rowley, 2014). This study was developed and adopted a set of measurements in order to measure study variables. All variables were measured based on the modified questionnaires (ASOSAI, 2009).

The present study has developed 5 items to measure the role of Supreme Audit Institutions(SAI) in reduce of audit failure. It includes. First, is the SAI free to determine the nature of its organizational structure and functional process without outside interference? Second, does the head of the SAI and "Members" for collegial bodies have legal immunity in the normal discharge of the duties in auditing of public sector? Third, does the SAI submit its Periodic / Annual report to Parliament? Fourthly, does the SAI have unrestricted access to the information in auditing of public sector? Finally, does the SAI have procedures to handle complaints \& allegations concerning failures to comply with professional standards and regulatory requirements of non-compliance with the SAI's system of quality control? The five elements were measured on a five-point scale ranging from $1=$ "strongly disagree" to $5=$ "strongly agree".

Audit Failures (AUF) was evaluated with 5 items, and the measurement items include the followings: First, are there adequate competencies and skills available to meet the requirement for executing SAI's mandate? Second, in recruiting personnel, does the SAI specify minimum qualifications as per the job description? Third, does the SAl have a mechanism in place that takes care of career planning and career development opportunities for staff members? Fourthly, are the plans meeting their objectives? finally, does the SAI have a system to objectively measure its results? This variable also adopts the five-point Likert scale as mentioned above.

Economic Development (ECD) was measured with 3 items as follows: First, does the SAI continuously able to address emerging issues in the rapidly changing political and economic environment of the country? Second, implementing real economic development requires enhanced audit quality and reduce of audit failures? Third, ensure that the institution's decision-making and control mechanism functions economically, efficiently, and effectively? The 3 items were measured based on a five-point scale ranging from 1= "strongly disagree" to $5=$ "strongly agree".

This study tested the hypotheses using the PLS-SEM. It is a statistical test to measure the relationship between one dependent variable and one or more independent variables 
(Monecke \& Leisch, 2012). while the SEM is popular and has been widely used in various disciplines. The PLS approach to SEM is considered as an alternative to covariance-based SEM, that is suitable even when data lacks normal distribution. The PLS path modelling approach is generally employed to estimate the causal relationships in the path models that involve latent constructs indirectly measured by several indicators (Hair et al., 2014). The presence of software applications like Smart PLS, PLS-SEM has become widespread in social sciences disciplines including accounting and auditing, and more generally, the PLS-SEM has been extensively utilized for the estimation of complex cause-effect relationship models, with latent variables (Hair et al., 2010).

\section{Results}

\section{Descriptive Statistics for Instrument}

A summary of the data was obtained by conducting the descriptive analysis procedure. This provided a general description of supreme audit institutions(SAI), audit failures(AUF), and lastly, economic development(ECD) from the perspective of the respondents. Table 1 shows that most items received different rankings in terms of the importance of supreme audit institutions. Which means their response is paralleled more to acceptance in this questionnaire. This result indicates that the respondents can differentiate between importance of supreme audit institutions and them reduce of audit failure and the impact of reduce audit failures on promote economic development.

Table 1: Descriptive statistics for instrument

\begin{tabular}{|l|l|l|l|}
\hline & Question Items & Mean & $\begin{array}{l}\text { Std. } \\
\text { Deviation }\end{array}$ \\
\hline SAI1 & $\begin{array}{l}\text { Supreme Audit Institutions(SAI) } \\
\text { meet the requirement for executing SAl's mandate? }\end{array}$ & 3.54 & .875 \\
\hline SAI2 & $\begin{array}{l}\text { In recruiting personnel, does the SAI specify minimum } \\
\text { qualifications as per the job description? }\end{array}$ & 3.49 & .863 \\
\hline SAI3 & $\begin{array}{l}\text { Does the SAI have a mechanism in place that takes care of } \\
\text { career planning and career development opportunities for } \\
\text { staff members? }\end{array}$ & 3.79 & .792 \\
\hline SAI4 & $\begin{array}{l}\text { Does the SAI have unrestricted access to the information in } \\
\text { auditing of public sector? }\end{array}$ & 3.63 & .856 \\
\hline SAI5 & $\begin{array}{l}\text { Does the SAI have procedures to handle complaints \& } \\
\text { allegations concerning failures to comply with professional } \\
\text { standards and regulatory requirements of non-compliance } \\
\text { with the SAI's system of quality control? }\end{array}$ & 3.59 & .836 \\
\hline AUf1 & $\begin{array}{l}\text { Are there adequate competencies and skills available to } \\
\text { meet the requirement for executing SAl's mandate? }\end{array}$ & 3.45 & .729 \\
\hline AUF2 & $\begin{array}{l}\text { In recruiting personnel, does the SAI specify minimum } \\
\text { qualifications as per the job description? }\end{array}$ & 3.31 & .738 \\
\hline
\end{tabular}




\begin{tabular}{|l|l|l|l|}
\hline AUF3 & $\begin{array}{l}\text { Does the SAl have a mechanism in place that takes care of } \\
\text { career planning and career development opportunities for } \\
\text { staff members? }\end{array}$ & 3.34 & .737 \\
\hline AUF4 & Are the plans meeting their objectives? & 3.63 & .549 \\
\hline AUF5 & $\begin{array}{l}\text { Does the SAI have a system to objectively measure its } \\
\text { results? }\end{array}$ & 3.50 & .758 \\
\hline ECD1 & $\begin{array}{l}\text { Economic development(ECD) } \\
\text { Does the SAl continuously able to address emerging issues } \\
\text { in the rapidly changing political and economic environment } \\
\text { of the country? }\end{array}$ & 3.85 & .745 \\
\hline ECD2 & $\begin{array}{l}\text { Implementing real economic development requires } \\
\text { enhanced audit quality and reduce of audit failures? }\end{array}$ & 3.78 & .655 \\
\hline ECD3 & $\begin{array}{l}\text { Ensure that the institution's decision-making and control } \\
\text { mechanism functions economically, efficiently, and } \\
\text { effectively? }\end{array}$ & 3.81 & .554 \\
\hline
\end{tabular}

\section{The Convergent Validity of the Measures}

Convergent validity is confirmed through different criteria including, factor loadings, composite reliability (CR) and average variance extracted (AVE) as proposed by Hair et al. (2010). The confirmation entails the examination of the items loadings. Table 2 lists the results of the examination and it indicates that the entire items obtained acceptable level based on the suggestions in literature concerning multivariate analysis (Hulland \& Richard, 1999; Hair et al., 2012). The items developed to measure a construct should reveal a higher loading on their respective construct in comparison to other constructs. Therefore, Loadings ranging from 0.40 to 0.60 can remain if the average variance extracted (AVE) exceeds 0.50 . Loadings over 0.60 are deemed to very acceptable in exploratory research as evidenced by (Hulland \& Richard, 1999; Hair et al., 2012). Table 2. shows that the items had high loading on their constructs compared to other constructs, and that the loadings significantly loaded on their constructs, confirming the measures' content validity (Chow \& Chan, 2008).

Moving on to the second aspect of convergent validity, which is the composite reliability this reliability shows the level to which a set of items are consistent in their indication of the latent construct (Hair et al., 2012). Based on literature, the composite reliability values should fall from $0.70-0.90$ in the later research stages to be considered as satisfactory (Hair et al., 2016). The items' composite reliability was accordingly examined and their values are presented in Table 2. All the values ranged from 0.822-0.868, which surpasses the recommended value of 0.70 (Hair et al., 2010). The results confirmed the outer model's convergent validity. Another way to confirm convergent validity of the outer model, which was also adopted in this study, is to calculate the average variance extracted. The AVE is a representation of the average of the variance obtained among a set of items in relation to the variance shared with the measurement errors. With AVE values of at least 0.5 , the set of items reveal sufficient convergence in their measurement of a construct (Hair et al., 2010; Hair et al., 2012). In the present study, the AVE values obtained ranged from 0.549 to 0.596 which shows a good construct validity level of the adopted measures. 
Table 2: Measurement model assessment

\begin{tabular}{|c|c|c|c|c|c|}
\hline \multirow[t]{2}{*}{ Construct Scale } & \multirow[t]{2}{*}{ Item } & \multicolumn{2}{|c|}{ Convergent Validity } & \multirow[t]{2}{*}{ CR } & \multirow{2}{*}{$\begin{array}{l}\text { Cronbach's } \\
\text { Alpha }\end{array}$} \\
\hline & & Loadings & AVE & & \\
\hline \multirow{5}{*}{ Supreme Audit Institutions } & SAI1 & 0.570 & \multirow{5}{*}{0.558} & \multirow{5}{*}{0.868} & \multirow{5}{*}{0.835} \\
\hline & SAI 2 & 0.593 & & & \\
\hline & SAI 3 & 0.732 & & & \\
\hline & SAI 4 & 0.838 & & & \\
\hline & SAI 5 & 0.761 & & & \\
\hline \multirow{5}{*}{ Audit Failures } & AUF1 & 0.715 & \multirow{5}{*}{0.549} & \multirow{5}{*}{0.859} & \multirow{5}{*}{0.802} \\
\hline & AUF 2 & 0.729 & & & \\
\hline & AUF 3 & 0.675 & & & \\
\hline & AUF 4 & 0.655 & & & \\
\hline & AUF 5 & 0.731 & & & \\
\hline \multirow{3}{*}{ Economic Development } & ECD1 & 0.686 & \multirow{3}{*}{0.596} & \multirow{3}{*}{0.822} & \multirow{3}{*}{0.716} \\
\hline & ECD2 & 0.576 & & & \\
\hline & ECD3 & 0.642 & & & \\
\hline
\end{tabular}

Path Coefficients and Hypotheses Testing

After the goodness of the outer model is established, the next step involves the testing of the proposed hypotheses among the constructs. In the structural model, every path that connects two latent variables is represented in a hypothesis. On the basis of the conducted analysis of the structural model, the researcher moved on to confirming the hypotheses and understanding the relationship strength between the dependent and independent variables. The path coefficients are confirmed to be statistically significant with the use of bootstrapping techniques, an integral tool in SmartPLS 3.0. In this regard, the $T$ values of each path coefficient were generated after which the $P$ values were depicted (refer to Table 3 ).

Table 3: Structural model assessment

\begin{tabular}{lllllll}
\hline & $\begin{array}{l}\text { Hypothesis } \\
\text { Pathway }\end{array}$ & $\begin{array}{l}\text { Path } \\
\text { Coefficient }\end{array}$ & $\begin{array}{l}\text { Standard } \\
\text { Error }\end{array}$ & t-value & P Values & Decision \\
\hline H1 & SAI -> AUF & 0.074 & 0.068 & 1.049 & 0.148 & Not Supported \\
\hline H2 & AUF -> ECD & 0.008 & 0.070 & 0.121 & 0.443 & Not Supported \\
\hline
\end{tabular}

Note: ${ }^{*} p<0.1, * * p<0.05, * * * p<0.01$

Table 3 shows the two direct proposed hypotheses tested and the results reveal that Supreme Audit Institutions (SAI) had no significant effect on reduce of audit failures (AUF) ( $\beta=0.074$, $\mathrm{t}=1.049, \mathrm{p}>0.1)$ indicating that $\mathrm{H} 1$ is rejected. Moving on to the result pertaining to audit failures (AUF) it was revealed to have a no effect on economic development (ECD) $(\beta=0.008$, $\mathrm{t}=0.121, \mathrm{p}>0.1$ ), indicating that $\mathrm{H} 2$ is also rejected.

\section{Conclusions}

Supreme Audit Institutions (SAIs) - key government agencies responsible for auditing how public funds are being spent - have been traditionally seen as insulated and technocratic entities serving difrent government organizations. This image was shaped by their function: 
SAls are in charge of checking whether public funds are being used for intended purposes efficiently, effectively, and economically in compliance with existing rules and regulations. "SAls are autonomous, independent, non-political organizations that audit governments to ensure the proper and effective use of public funds; the development of sound financial management; the proper execution of administrative activities; and the communication of information to public authorities and the general public through the publication of objective reports". Supreme Audit Institutions (SAIs) - key government agencies responsible for auditing how public funds are being spent - have been traditionally seen as insulated and technocratic entities serving different government organizations. This image was shaped by their function: SAls are in charge of checking whether public funds are being used for intended purposes efficiently, effectively, and economically in compliance with existing rules and regulations.

In the past few years, audit quality has attracted attention as a tool used to assess the auditing effectiveness and in recent times increasing importance has been placed on SAIS to conduct quality auditing. In this regard, auditing failures have led to debates concerning the new requirement in place to reinforce quality auditing. In prior studies, audit failures have been evidenced to tarnish auditor reputation through loss of market share. In this background, quality of audit may be considered conceptually as a continuum that ranges from very low to very high audit quality. In addition, audit failures arise on the lower quality continuum, while audit quality is at the opposite, with the former having the possibility of leading to business failure, corruption as well as other negative consequences. corruption happens on a global level in different ways and forms notwithstanding the development level of the country. More recently, there is increased public outcry in Iraq on the government's wastage of public spending, corruption, high recurrent expenditures, governance costs and ineffective budget performance by different government entities. In this regard, public sector corruption is rife in Iraq, especially among the public officials in the higher echelons and it has the potential to lessen economic development and good country governance.

The environment of the public sector audit generally has a monopolistic nature with the SAls responsible for government auditing. The SAls have different roles and functions that are important to the public, the legislature as well as the government and they have different audits and inspections roles in different entities of the government. SAls are basically independent, non-political entities that perform auditing for governments in order to make sure that public funds are effectively and properly used, administrative activities are properly executed and communication of information to relevant public authorities and the public through reports publication are ensured. Therefore, it is crucial that SAls become the linchpin of the integrity of the country as they are responsible for auditing government income and expenditure, the watchdog over financial integrity and the credibility of information provided. In fact, the SAls efforts to lessen corruption are its major contribution in preventing corruption and in supporting accountability and transparency with the main aim of supporting a robust financial-management system.

This study has future implications for further studies. future studies may venture further and examine the audit failures (AUF) of other countries facing the same issue especially in public sector audit, with the public demanding audit quality accountability by SAls. Presently, achieving top quality audit work is in demand, so the audit process has to be aligned with this change and this requires the replication of the present study in different contexts, especially 
in other developing countries. This would enable the development of the basis for comparison of findings.

\section{References}

Clark, C., Martinis, D. M., \& Krambia-Kapardis, M. (2007). Audit quality attributes of European Union supreme audit institutions. European Business Review, 19(1), 40-71.

Monecke, A. \& Leisch, F. (2012). SEM-PLS: structural equation modeling using partial least squares. University of Wollongong Australia, 48 (3), 1-32.

Trotman, A. J. (2013). Internal Audit Quality: Amulti-Stakeholder Analysis (Doctoral dissertation, Bond University Australia).

Abdul-Hussein, M (2013). Supervision of the Office of the Federal financial control over the executive bodies and its role in the administrative reform and support the government's performance, Baghdad University.

Hair, J. F., Hult, G. T. M., Ringle, C. \& Sarstedt, M. (2016). A primer on partial least squares structural equation modeling (PLS-SEM). Sage Publications.

Trotman, A. J. (2013). Internal Audit Quality: Amulti-Stakeholder Analysis (Doctoral dissertation, Bond University Australia).

Ratsula, O. P. (2010). The Interplay between Internal Governance Structures, Audit Fees and Earnings Management in Finnish Listed Companies.

Xi, J. (2013). PCAOB inspection report outcomes: Do they reflect audit quality and audit clients' levels of governance and controls? (Doctoral dissertation, RMIT University).

Alkafaji, Y. A. (2007). Quality assurance review programs of auditing firms: an international perspective. Managerial Auditing Journal, 22(7), 644-660.

Ahmad, M. B. (2012). Auditor independence in Malaysia: the perceptions of loan officers and professional investors (Doctoral dissertation, Cardiff University).

Elghrabawy, A. (2012). A contingency framework of enterprise governance in the UK: A valuebased management approach (Doctoral dissertation, Brunel University Brunel Business School PhD Theses).

Ratsula, O. P. (2010). The Interplay between Internal Governance Structures, Audit Fees and Earnings Management in Finnish Listed Companies.

Hulland, J. \& Richard Ivey School of Business. (1999). Use of partial least squares (PLS) in strategic management research: A review of four recent studies. Strategic Management Journal, 20(2), 195-204.

Hair, J. F., Sarstedt, M., Pieper, T. M. \& Ringle, C. M. (2012). The Use of Partial Least Squares Structural Equation Modeling in Strategic Management Research: A Review of Past Practices and Recommendations for Future Applications. Long Range Planning 45, 320-340.

Morrison, III., T. D., \& Shough, S. (2009). The impact of the new AICPA peer review standards on small CPA firms. In Allied Academies International Internet Conference (Vol. 11, p. 18).

Chow, W. S. \& Chan, L. S. (2008). Social network, social trust and shared goals in organisational knowledge sharing. Information \& Management, 45(7), 458-465.

Sharman, J. C. (2008), "Power and discourse in policy diffusion: anti-money laundering in Developing states", International Studies Quarterly, Vol. 635, pp. 635, 642. 
Richards, P. J., Devinney, T. M., Yip, G. S., \& Johnson, G. (2008). Measuring organizational performance as a dependent variable: Towards methodological best practice. Strategic Management Journal.

Sevilla, J. (2005). Accountability and control of public spending in a decentralized and

Deregulated environment. OECD Journal on Budgeting,5(2),7-21.

Dye, K. M., \& Stapenhurst, R. (1998). Pillars of integrity: the importance of supreme audit institutions in curbing corruption. Economic Development Institute of the World Bank.

TAS, D. (2012). Endemic corruption in the Iraqi public sector: Can anti-money laundering measures provide the cure? Journal of Money Laundering Control, 15(4), 458-482.

Borge, M. (1999), "The role of supreme audit institutions (SAIs) in combating corruption", School of Advanced International Studies.

Sweeney, B (2001). Management control in audit firms, A Dissertation submitted to Dublin City University, Business School- September.

Kayrak, M. (2008). Evolving challenges for supreme audit institutions in struggling with corruption. Journal of Financial Crime, 15(1), 60-70.

Beattie, V., \& Fearnley, S. (2010). Auditor independence and non-audit services: A literature review. Institute of Chartered Accountants in England and Wales, London.

Fafatas, S. A. (2010). Auditor conservatism following audit failures. Managerial Auditing Journal, 25(7), 639-658.

Hagman Mendonca, S., \& Persson, L. (2014). Audit Quality from a Client Company Perspective-Drivers of audit quality and the effects of a voluntary audit firm rotation.

Ibrahim, M. (2010). State Audit Institution in United Arab Emirates. International Journal of Law and Management, 52(6), 464-468.

Rankokwane, B. (2008). an evaluation of the role of supreme audit institutions in promoting environmental accountability-the case of the office of the auditor general, gaboronebotswana.

Karapetrovic, S., \& Willborn, W. (2000). Quality assurance and effectiveness of audit systems. International Journal of Quality \& Reliability Management, 17(6), 679-703.

Mendonca, H. S., \& Persson, L. (2014). Audit Quality from a Client Company PerspectiveDrivers of audit quality and the effects of a voluntary audit firm rotation.

Hamdan, H. K. (2011) The role of the Federal Board of Supreme Audit of Iraq (FBSA) in quality control, Qadisiyah Journal of administrative and economic sciences. Volume 13, Issue 3.

Odia, J. O. (2014). Performance Auditing and Public Sector Accountability in Nigeria: The Roles of Supreme Audit Institutions (SAls). Asian Journal of Management Sciences \& Education Vol, 3, 2.

Fafatas, S. A. (2010). Auditor conservatism following audit failures. Managerial Auditing Journal, 25(7), 639-658.

Francis, J. R. (2004). What do we know about audit quality? The British accounting review, 36(4), 345-368.

Bing, J. J., Huang, C. X., Li, A. L., \& Zhu, X. L. (2014). Audit Quality Research Report.

Sevilla, J. (2005).Accountability and control of public spending in a decentralized and deregulated environment. OECD Journal on Budgeting, 5(2), 7-21.

Kayrak, M. (2008). Evolving challenges for supreme audit institutions in struggling with corruption. Journal of Financial Crime, 15(1), 60-70.

Power, M. (1997), the Audit Society - Rituals of Verifications, Oxford University Press. 
Fan, H., Mir, M., \& Maclean, I. (2012) The Independence of Supreme Audit Institutions in the Context of Democracy and Political Competitions: The Case of Chinese National Audit Office.

Dye, M. K. and Stapenhurst, R. (1998), Pillars of Integrity: The Importance of Supreme Audit Institutions in Curbing Corruption, World Bank, Washington, DC.

Borge, M. (1999), "The role of supreme audit institutions (SAIs) in combating corruption", School of Advanced International Studies

Nuri, S., \& AL- Lahibi, I. (2013). Suggested Model for activating the role of the regulators for the auditing profession in achieving quality audit, Journal of Accounting and Financial Studies Volume, university of Baghdad, No. 23. 